\title{
Delay causes in road infrastructure projects in developing countries
}

Guillermo Mejía (Main and Corresponding Author)

Civil Engineering Department, Universidad Industrial de Santander

P.O. Box 680002, Bucaramanga, Santander (Colombia)

gmejia@uis.edu.co

\section{Omar Sánchez}

Civil Engineering Department, Universidad Industrial de Santander P.O. Box 680002, Bucaramanga, Santander (Colombia)

omar.sanchez@correo.uis.edu.co

\section{Karen Castañeda}

Civil Engineering Department, Universidad Industrial de Santander P.O. Box 680002, Bucaramanga, Santander (Colombia)

karencasta.ing@outlook.es

\section{Eugenio Pellicer}

School of Civil Engineering, Universitat Politècnica de València

Camino de Vera, s/n, 46022 Valencia (Spain)

pellicer@upv.es

Manuscript Code: 14062

Date of Acceptance/Reception: 27.07.2020/18.09.2019

DOI: 10.7764/RDLC.19.2.220

\begin{abstract}
Project delays adversely affect road infrastructure development in developing countries. Unfavorable consequences of project delays involve cost overrun, contractual disputes, arbitration, and quality non-conformities. Despite these risks, literature shows that delays are still a prevalent problem in construction management. Although there is a considerable number of publications on project delays, few studies have compared their causes between developing countries. Therefore, this study aimed to: a) classify and determine the level of influence of the delay causes; b) find the relationship between delay causes and country's development; and c) propose recommendations for mitigating the most critical causes in developing countries. A systematic literature review provided a sample of 14 primary studies from Africa (50\%) and Asia (50\%). Based on this sample, the study found that developing countries, with a GDP per capita (\$US2018) $<=\$ 2,000$, may experience different delay causes depending on the economic and the geographical contexts. In African countries with a Global Competitiveness Index $-\mathrm{GCl}<=56$, road projects may experience delays due to financial issues of the project owner, as well as delays due to equipment/material issues of the project supplier/subcontractor. On the other hand, in Asian countries with a $\mathrm{GCl}$ between 62 and 49 , road projects may experience delays due to financial issues of the project contractor, and delays due to planning issues of the project designer/consultant. According to these economic contexts, this study proposes a frame of causes and mitigation actions as a contribution to the risk analysis of road projects in developing countries.
\end{abstract}

Keywords: delay causes, delay factors, road projects, road infrastructure, systematic review.

Infrastructure is a fundamental factor of the Global Competitiveness Index (GCI). This index assesses the ability of countries to provide high living standards to their citizens (Schwab, 2018). An infrastructure with high-quality roads enables markets to trade goods and services in a secure and timely manner. Indeed, road infrastructure projects provide better conditions for accessing health, education, employment, and other social aspects, both in rural and urban regions (Amoatey \& Okanta, 2017; Santoso \& Soeng, 2016). Hence, national road infrastructure strategies and projects are essential for improving living standards in developing countries.

The World Economic Forum annually measures the improvement in living standards of 140 countries, based on a set of 12 factors that makes up the $\mathrm{GCl}$. The last reports of the $\mathrm{GCl}$ 's infrastructure factor indicate better-connected geographic regions have been more prosperous (Schwab, 2018). This evidence shows better $\mathrm{GCl}$ indices correlate with successful developments of road infrastructure projects. Successful project development implies delivering projects within time and budget, a challenge for construction management (Amoatey \& Okanta, 2017).

For road construction projects, timely project completion is a critical success factor (Aziz \& Abdel-hakam, 2016), yet project delays are still a prevalent issue (Ellis, 2003; Honrao \& Desai, 2015). For instance, Amoatey \& Okanta (2017) found that $70 \%$ of 48 road projects built in Ghana experienced delays, with an average time overrun of 17 months. 
Elawi, Algahtany, Kashiwagi, \& Sullivan (2015) analyzed 49 infrastructure projects executed in Saudi Arabia, whose timeoverrun was, on average, 39\%. Mahamid (2017a) examined 101 road projects in Palestine and determined an average delay of $48 \%$. This frequent issue has lead researchers to study project delays in construction management more indepth.

One of the benefits of thoroughly studying delay causes is the mitigation of adverse impacts on project performance. Project delay must be managed and mitigated before it grows and influences project cost performance (Santoso \& Soeng, 2016). The first step for mitigating delays is the identification of causes for proposing corrective actions (Kamanga \& Steyn, 2013). Although a plethora of research has been undertaken to identify the delay causes in construction, few studies have compared delay causes between countries of similar competitiveness.

\section{Related studies on project delays}

A preliminary search of studies reported between 2000 and 2019 in the SCOPUS ${ }^{\circledR}$ database found an evident growth of relevant publications over the last years. The search identified 746 papers, with the keywords "delay and construction projects". This considerable number of publications on delays allows researchers to conduct comparative analyses of road projects between countries of similar competitiveness.

Most of the studies reported findings according to single country development. There were studies in countries with GDP per capita (2018 US\$) > 10,000, such as South Korea (Kavuma, Ock, \& Jang, 2019) and the United Kingdom (Agyekum \& Knight, 2017). There were also studies in countries with GDP per capita (2018 US\$) between 10,000 and 2,000, such as Turkey (Budayan, 2019) and Algeria (Rachid, Toufik, \& Mohammed, 2018), as well as studies in countries with GDP per capita (2018 US\$) < 2,000 like Sudan (Khair, Mohamed, Mohammad, Farouk, \& Ahmed, 2017) and Cambodia (Durdyev, Omarov, \& Ismail, 2017). However, the search found scarce comparative studies. For instance, Arditi, Nayak, \& Damci (2017) compared organizational influencing factors on project delays, between the USA and Indian projects; Kadry, Osman, \& Georgy (2017) compared influencing factors between high-risk countries, and Mahdi \& Soliman (2018) compared the delay factors of three developed countries. However, there is a lack of comparative studies with mitigation proposals for delays of road infrastructure projects in developing countries.

This study aimed to: a) classify and determine the influence on the project delay of the most relevant delay causes, b) find relationships between the most critical delay causes and the country's development, and c) propose recommendations for mitigating the most critical delay causes. The classification of the delays studied here is according to both main construction management topics and project stakeholders, as well as the determination of the influence, based on the relative importance index (RII) and the influence index (II). The following sections of this paper will explain the research method used for achieving these objectives and will discuss the findings. The last part of this paper will describe some recommendations for dealing with delay issues in road infrastructure projects in developing countries.

Methodology

This research used a systematic review of the specialized literature to achieve its objectives. The reviewing team searched and evaluated primary studies, collected evidence, summarized the results, and drew further conclusions. Thus, these results constitute formal evidence to improve practice and to generalize patterns (Borrego, Foster, \& Froyd, 2014; Cooper, Hedges, \& Valentine, 2009).

The first steps of the systematic review were searching and selecting relevant studies, published under a blind peer review policy, through Scopus and Web of Science databases. The Boolean equations used combinations of keywords with the operators "AND" and "OR." As keywords related to project type, the equations included "road", "highway", and "motorway"; the keywords associated with the object of study were "delay", "time overrun", "time deviation", "schedule delay", "schedule deviation", and "schedule overrun"; finally, as qualifiers of the research object the equations included "causes", "factors", and "reasons". Next, the process identified 746 preliminary papers, and then selected a final sample of 14 studies (see Figure 1), filtered through the following inclusion/exclusion rules:

- Rule \#1: the document reports quantitative evidence of delay causes.

- Rule \#2: the document focuses on roads or highways projects.

- Rule \#3: the document ranks the top ten, or more, delay causes. 


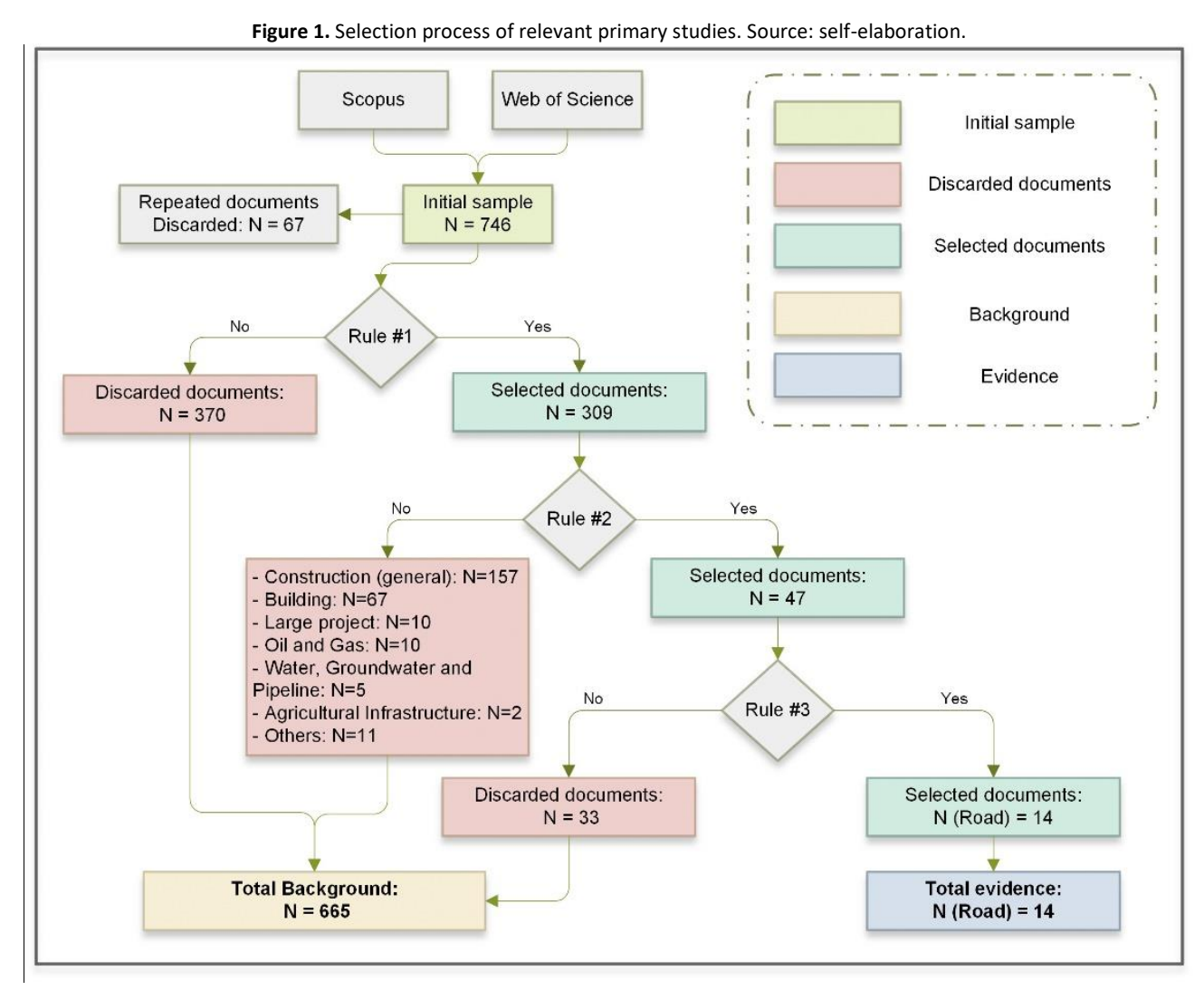

\section{Sample composition and description}

The final sample of 14 primary studies provided the initial delay causes for the analysis. The number of causes reported per study varied between 14 and 293, with an average of 63 causes per each; the number of categories per study varied between 1 and 15, with an average of six categories per each (see Table 1). The variety of causes and types reported by primary studies indicates there is no consensus among academics and practitioners about standardizing causes and categories of project delays. This research found that the categories proposed by primary studies are not mutually exclusive.

For this study, the top ten causes reported by each study led researchers to identify 140 relevant delay causes. Based on an affinity criterion, all of these causes were renamed into 41 initial delay causes. Next, these causes were classified by affinity into both a set of ten mutually exclusive categories related to project management topics (see Table 2) and a set of five mutually exclusive categories related to project stakeholders (see Table 3).

The composition by region of the final sample showed that $50 \%$ of the primary studies were from Asia (7 out of 14) and $50 \%$ from Africa (7 out of 14). The Asian studies were carried out in Cambodia, India, Iraq, Pakistan, and Palestine, while those African studies were carried out in Algeria, Egypt, Ghana, Libya, Malawi, Sudan, and Zambia (see Table 1).

\begin{tabular}{|c|c|c|c|c|c|c|}
\hline Reference & Country & Area & Respondents & $\begin{array}{c}\text { Sample } \\
\text { Size }\end{array}$ & $\begin{array}{l}\text { Number of } \\
\text { delay causes }\end{array}$ & $\begin{array}{l}\text { Number of } \\
\text { categories }\end{array}$ \\
\hline (Rachid et al., 2018) & Algeria & Africa & $\begin{array}{l}\text { Contractors (16), } \\
\text { Consultants (20), } \\
\text { Owners (16) }\end{array}$ & 52 & 55 & 9 \\
\hline $\begin{array}{l}\text { (D. S. Santoso \& } \\
\text { Soeng, 2016) }\end{array}$ & Cambodia & Asia & $\begin{array}{l}\text { Contractors (82), } \\
\text { Consultants (71) }\end{array}$ & 153 & 64 & 5 \\
\hline $\begin{array}{l}\text { (Aziz \& Abdel-hakam, } \\
\text { 2016) }\end{array}$ & Egypt & Africa & $\begin{array}{l}\text { Contractors (131), } \\
\text { Consultants (36), } \\
\text { Site/design } \\
\text { engineers (19) }\end{array}$ & 186 & 293 & 15 \\
\hline $\begin{array}{l}\text { (Amoatey \& Okanta, } \\
\text { 2017) }\end{array}$ & Ghana & Africa & $\begin{array}{l}\text { Contractors (35), } \\
\text { Consultants (28), } \\
\text { Clients (40), } \\
\text { Donors (20) }\end{array}$ & 123 & 23 & 4 \\
\hline
\end{tabular}




\begin{tabular}{|c|c|c|c|c|c|c|}
\hline Reference & Country & Area & Respondents & $\begin{array}{l}\text { Sample } \\
\text { Size }\end{array}$ & $\begin{array}{c}\text { Number of } \\
\text { delay causes }\end{array}$ & $\begin{array}{l}\text { Number of } \\
\text { categories }\end{array}$ \\
\hline $\begin{array}{l}\text { (Venkateswaran \& } \\
\text { Murugasan, 2017) }\end{array}$ & India & Asia & $\begin{array}{l}\text { Contractors (17), } \\
\text { Consultants (18), } \\
\text { Owners (27) }\end{array}$ & 62 & 29 & 1 \\
\hline $\begin{array}{l}\text { (Pai, Patnaik, Mittal, } \\
\text { \& Anand, 2018) }\end{array}$ & India & Asia & $\begin{array}{l}\text { Contractors (7), } \\
\text { Consultants (34), } \\
\text { Clients (12) }\end{array}$ & 53 & 47 & 6 \\
\hline (Hadithi, 2018) & Iraq & Asia & $\begin{array}{l}\text { Contractors (28), } \\
\text { Consultants (6), } \\
\text { Owners (13) }\end{array}$ & 47 & 64 & 5 \\
\hline $\begin{array}{l}\text { (Alfakhri, Ismail, } \\
\text { Muhamad, Arhad, \& } \\
\text { Irtema, 2017) }\end{array}$ & Libya & Africa & $\begin{array}{l}\text { Contractors (69), } \\
\text { Consultants (77), } \\
\text { Owners (110) }\end{array}$ & 256 & 59 & 8 \\
\hline $\begin{array}{l}\text { (Kamanga \& Steyn, } \\
\text { 2013) }\end{array}$ & Malawi & Africa & $\begin{array}{l}\text { Contractors (20), } \\
\text { Consultants (12), } \\
\text { Clients (13) }\end{array}$ & 45 & 72 & 6 \\
\hline $\begin{array}{l}\text { (Sohu, Chandio, \& } \\
\text { Keleemullah, 2019) }\end{array}$ & Pakistan & Asia & $\begin{array}{l}\text { Contractors (60), } \\
\text { Consultants (30), } \\
\text { Clients (40) }\end{array}$ & 130 & 26 & 1 \\
\hline $\begin{array}{l}\text { (Mahamid, Bruland, \& } \\
\text { Dmaidi, 2012) }\end{array}$ & Palestine & Asia & $\begin{array}{l}\text { Contractors (34), } \\
\text { Consultants (30) }\end{array}$ & 64 & 52 & 8 \\
\hline (Mahamid, 2017a) & Palestine & Asia & $\begin{array}{l}\text { Contractors (40), } \\
\text { Consultants (30) }\end{array}$ & 70 & 20 & 1 \\
\hline (Khair et al., 2017) & Sudan & Africa & $\begin{array}{l}\text { Contractors (19), } \\
\text { Consultants (30), } \\
\text { Owners (10), } \\
\text { Government } \\
\text { policies (41) }\end{array}$ & 100 & 66 & 6 \\
\hline $\begin{array}{l}\text { (Kaliba, Muya, \& } \\
\text { Mumba, 2009) }\end{array}$ & Zambia & Africa & 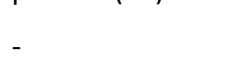 & 26 & 14 & 1 \\
\hline
\end{tabular}

\section{Measuring the influence of delay causes}

The study computed the level of influence for each cause based on the relative importance index (RII), the frequency, and the influence index (II). The RII is a primary influence measure of the delay causes, as perceived by owners, contractors, and consultants. To compute the RII, first, an inverse rank $(I R)$ was calculated for each delay cause, taking into account the position reported $(R R)$ by the primary study in Equation (1) (Sánchez, Castañeda, Herrera, \& Pellicer, 2019).

$$
I R=10-(R R-1) \text { Equation (1) }
$$

Next, the RII for each delay cause was computed with the Equation (2), an adaption of the RII used by the Amoatey and Okanta's study (2017).

$$
R I I=\frac{\sum I R}{I R \max \times N} \text { Equation (2) }
$$

Where: $I R$ is the inverse rank for each delay cause; IRmax is the maximum IR value $(I R m a x=10) ; N$ is the total number of primary studies $(N=14)$. Finally, the level of influence for this study was computed according to Equation (3), an adaption of the importance index used by Santoso \& Soeng (2016).

$$
I I=R I I x \text { frequency Equation }
$$

To sum up the findings and draw conclusions, a further statistical analysis based on contingency tables tested the relationship between delay cause and region of the primary study (i.e., Africa and Asia). Additionally, the study computed the relative risk (RR), an effect size or likelihood of occurrence of the relationship between variables (Elliott \& Woodward, 2007). 
This section shows and discusses the results in the following order: First, the categorization of causes with respect to the project management topics and project stakeholders. Next, the relative risk of the most frequent delay causes. Then, the delays in decreasing order according to level of influence. Next, the statistical evidence of the relationship between delay causes and region of the primary studies. Finally, the recommendations for mitigating the most critical delay causes, according to their respective categories and the country's level of development.

\section{Classification of project delay causes}

\section{Delay causes by project management topic}

The 41 delay causes most reported by the primary studies were classified into ten mutually exclusive categories related to the main project management topics (see Table 2).

Table 2. Frequency of delays by project management topics $(N=140)$. Source: self-elaboration.

\begin{tabular}{|c|c|c|c|}
\hline \multicolumn{2}{|c|}{ Delay Causes by Category } & Frequency & Percentage (\%) \\
\hline \multicolumn{4}{|c|}{ Financial issues $(24 / 140=17.1 \%)$} \\
\hline C01 & Payment delays to contractor & 10 & 7.1 \\
\hline $\mathrm{CO2}$ & Financial difficulties of contractor & 5 & 3.6 \\
\hline C03 & Financial difficulties of owner & 9 & 6.4 \\
\hline \multicolumn{4}{|c|}{ Contract management and skills $(19 / 140=13.6 \%)$} \\
\hline C08 & Lack of owner's management skills & 2 & 1.4 \\
\hline $\mathrm{C} 13$ & Inadequate contractor's experience & 6 & 4.3 \\
\hline C35 & Poor contract management & 1 & 0.7 \\
\hline C36 & Unrealistic contract duration & 3 & 2.1 \\
\hline $\mathrm{C} 37$ & Claims and disputes with stakeholders & 2 & 1.4 \\
\hline C38 & Poor communication with stakeholders & 5 & 3.6 \\
\hline \multicolumn{4}{|c|}{ Change management $(15 / 140=10.7 \%)$} \\
\hline C05 & Change orders due to the owner & 2 & 1.4 \\
\hline $\mathrm{CO6}$ & Scope changes due to the owner & 2 & 1.4 \\
\hline C10 & Late decision making by owner & 5 & 3.6 \\
\hline C16 & Late decision making by consultants & 2 & 1.4 \\
\hline $\mathrm{C} 22$ & Project scope changes & 4 & 2.9 \\
\hline \multicolumn{4}{|c|}{ Project planning issues $(15 / 140=10.7 \%)$} \\
\hline C09 & Land acquisition & 3 & 2.1 \\
\hline $\mathrm{C} 20$ & Inadequate project planning & 6 & 4.3 \\
\hline $\mathrm{C} 21$ & Lack of project planning & 1 & 0.7 \\
\hline $\mathrm{C} 23$ & Inadequate bidding method & 2 & 1.4 \\
\hline C33 & Poor site investigation & 3 & 2.1 \\
\hline \multicolumn{4}{|c|}{ Site management $(15 / 140=10.7 \%)$} \\
\hline C11 & Delayed activities & 5 & 3.6 \\
\hline $\mathrm{C} 12$ & Inadequate construction methods & 1 & 0.7 \\
\hline $\mathrm{C} 14$ & Poor site management and supervision & 7 & 5.0 \\
\hline C31 & Delay of site mobilization & 2 & 1.4 \\
\hline \multicolumn{4}{|c|}{ External influences $(15 / 140=10.7 \%)$} \\
\hline C39 & Late permits by local authorities & 2 & 1.4 \\
\hline $\mathrm{C} 40$ & Economy issues & 3 & 2.1 \\
\hline C41 & Political situation & 4 & 2.9 \\
\hline $\mathrm{C} 42$ & Unethical activities & 2 & 1.4 \\
\hline C43 & Weather & 4 & 2.9 \\
\hline \multicolumn{4}{|c|}{ Equipment and materials issues $(13 / 140=9.3 \%)$} \\
\hline C04 & Price variation of materials & 2 & 1.4 \\
\hline C29 & Shortage of equipment & 6 & 4.3 \\
\hline C30 & Shortage of materials & 5 & 3.6 \\
\hline \multicolumn{4}{|c|}{ Design issues $(10 / 140=7.1 \%)$} \\
\hline C07 & Late approval of shop drawings and sample materials & 2 & 1.4 \\
\hline $\mathrm{C} 17$ & Delays of design & 1 & 0.7 \\
\hline
\end{tabular}




\begin{tabular}{|c|c|c|c|}
\hline \multicolumn{2}{|c|}{ Delay Causes by Category } & \multirow{2}{*}{$\frac{\text { Frequency }}{3}$} & \multirow{2}{*}{$\frac{\text { Percentage (\%) }}{2.1}$} \\
\hline C18 & Design changes & & \\
\hline C19 & Failures in design & 4 & 2.9 \\
\hline \multicolumn{4}{|c|}{ Project characteristics $(7 / 140=5.0 \%)$} \\
\hline C24 & Project size & 1 & 0.7 \\
\hline C32 & Ground conditions & 3 & 2.1 \\
\hline C34 & Relocation of underground utilities & 3 & 2.1 \\
\hline \multicolumn{4}{|c|}{ Workforce/Labor Issues (7/140 = 5.0\%) } \\
\hline $\mathrm{C} 25$ & Low labor productivity & 4 & 2.9 \\
\hline $\mathrm{C} 26$ & Shortage of labor & 2 & 1.4 \\
\hline $\mathrm{C} 27$ & Staffing problems & 1 & 0.7 \\
\hline
\end{tabular}

\section{Delay causes by project stakeholder}

Furthermore, the 41 delay causes most reported by the primary studies were classified into five mutually exclusive categories related to project stakeholders (see Table 3).

Table 3. Frequency of delays by stakeholder $(\mathrm{N}=140)$. Source: self-elaboration

\begin{tabular}{|c|c|c|c|}
\hline \multicolumn{2}{|c|}{ Delay Causes by Category } & Frequency & Percentage (\%) \\
\hline \multicolumn{4}{|c|}{ Owner $(50 / 140=35.7 \%)$} \\
\hline C01 & Payment delays to contractor & 10 & 7.1 \\
\hline $\mathrm{CO3}$ & Financial difficulties of owner & 9 & 6.4 \\
\hline C05 & Change order due to owner & 2 & 1.4 \\
\hline $\mathrm{C06}$ & Scope change due to owner & 2 & 1.4 \\
\hline $\mathrm{C08}$ & Lack of owner's management skills & 2 & 1.4 \\
\hline C09 & Land acquisition & 3 & 2.1 \\
\hline C10 & Late decision making by owner & 5 & 3.6 \\
\hline $\mathrm{C} 20$ & Inadequate project planning & 7 & 5.0 \\
\hline $\mathrm{C} 22$ & Project scope changes & 4 & 2.9 \\
\hline $\mathrm{C} 23$ & Inadequate bidding method & 2 & 1.4 \\
\hline $\mathrm{C} 24$ & Project size & 1 & 0.7 \\
\hline C36 & Unrealistic contract duration & 3 & 2.1 \\
\hline \multicolumn{4}{|c|}{ Contractor $(32 / 140=22.9 \%)$} \\
\hline C02 & Financial difficulties of contractor & 4 & 2.9 \\
\hline C11 & Delayed activities & 6 & 4.3 \\
\hline C12 & Inadequate construction methods & 1 & 0.7 \\
\hline C13 & Inadequate contractor's experience & 7 & 5.0 \\
\hline C14 & Poor site management and supervision & 5 & 3.6 \\
\hline $\mathrm{C} 25$ & Low labor productivity & 1 & 0.7 \\
\hline $\mathrm{C} 27$ & Staffing problems & 5 & 3.6 \\
\hline C31 & Delay in site mobilization & 1 & 0.7 \\
\hline C35 & Poor contract management & 2 & 1.4 \\
\hline \multicolumn{4}{|c|}{ External Agent $(24 / 140=17.1 \%)$} \\
\hline C04 & Price variation of materials & 2 & 1.4 \\
\hline C37 & Claims and disputes with stakeholders & 2 & 1.4 \\
\hline C38 & Poor communication with stakeholders & 5 & 3.6 \\
\hline C39 & Late permits by local authorities & 2 & 1.4 \\
\hline $\mathrm{C} 40$ & Economy issues & 3 & 2.1 \\
\hline C41 & Political situation & 4 & 2.9 \\
\hline $\mathrm{C} 42$ & Unethical activities & 2 & 1.4 \\
\hline $\mathrm{C} 43$ & Weather & 4 & 2.9 \\
\hline \multicolumn{4}{|c|}{ Designer and Consultant $(21 / 140=15.0 \%)$} \\
\hline $\mathrm{CO7}$ & Late approval of shop drawings and sample materials & 2 & 1.4 \\
\hline C16 & Late decision making by consultants & 2 & 1.4 \\
\hline C17 & Delays of design & 1 & 0.7 \\
\hline C18 & Design changes & 3 & 2.1 \\
\hline C19 & Failures of design & 4 & 2.9 \\
\hline C32 & Ground conditions & 3 & 2.1 \\
\hline
\end{tabular}


C33 Poor site investigation

C34 Relocation of underground utilities

Supplier and Subcontractor $(13 / 140=9.3 \%)$

C26 Shortage of labor

C29 Shortage of equipment

C30 Shortage of materials
3

3

2

6

5
2.1

2.1

1.4

4.3

3.6

\section{Frequency of project delay causes}

The frequency analysis by project management topic indicated that those delay causes related to financing issues were the most reported by the primary studies, followed by those related to contract management.

Further analysis by region showed that within the "financial issues" category, 71\% (17 out of 24) of their related causes were reported by African studies. On the contrary, within the "contract management and skills" category, $63 \%$ (12 out of 19) of their associated causes were reported by Asian studies. Notably, the analysis showed that the causes related to "change management" were reported in equal proportion by both regions (see Table 4).

Based on Table 4, this research found that the "financial issues" category as the source of the delay was 2.4 (70.8/29.2) times more prevalent in African than in Asian countries. On the contrary, the "external influences" category was 2.7 (73.3/26.7) times more prevalent in Asian than in African countries. Moreover, the measure of RR showed that, in African countries, the "financing issues" category is 2.7 (70.8/26.7) times more likely to be a source of delays compared to "external influences." On the contrary, in Asian countries, the "external influences" category is 2.5 (73.3/29.2) times more likely to be a source of delays compared to "financing issues."

Table 4. Frequency of delays related to project management topic by region. Source: self-elaboration.

\begin{tabular}{|c|c|c|c|}
\hline Delay Category & Africa & Asia & Total \\
\hline Financial issues (17.1\%) & 17 & 7 & 24 \\
\hline$\%$ within category & $70.8 \%$ & $29.2 \%$ & $100 \%$ \\
\hline Contract management and skills (13.6\%) & 7 & 12 & 19 \\
\hline$\%$ within category & $36.8 \%$ & $63.2 \%$ & $100 \%$ \\
\hline Change management (10.7\%) & 7 & 8 & 15 \\
\hline$\%$ within category & $46.7 \%$ & $53.3 \%$ & $100 \%$ \\
\hline Project planning issues (10.7\%) & 5 & 10 & 15 \\
\hline$\%$ within category & $33.3 \%$ & $66.7 \%$ & $100 \%$ \\
\hline Site management (10.7\%) & 11 & 4 & 15 \\
\hline$\%$ within category & $73.3 \%$ & $26.7 \%$ & $100 \%$ \\
\hline External influences (10.7\%) & 4 & 11 & 15 \\
\hline$\%$ within category & $26.7 \%$ & $73.3 \%$ & $100 \%$ \\
\hline Equipment and materials issues (9.3\%) & 9 & 4 & 13 \\
\hline$\%$ within category & $69.2 \%$ & $30.8 \%$ & $100 \%$ \\
\hline Design issues (7.1\%) & 4 & 6 & 10 \\
\hline$\%$ within category & $40.0 \%$ & $60.0 \%$ & $100 \%$ \\
\hline Project characteristics (5.0\%) & 3 & 4 & 7 \\
\hline$\%$ within category & $42.9 \%$ & $57.1 \%$ & $100 \%$ \\
\hline Workforce/Labor Issues (5.0\%) & 3 & 4 & 7 \\
\hline$\%$ within category & $42.9 \%$ & $57.1 \%$ & $100 \%$ \\
\hline
\end{tabular}

The frequency analysis by stakeholder-categories found that one-third of the leading causes was associated with project owners, another third with contractors/subcontractors, and the other, with designers/consultants.

Further analysis by region showed that within the "owner" category, 60\% (30 out of 50) of their related cause were reported by African studies. On the contrary, within the "external" category, 79\% (19 out of 24) of their associated causes were reported by Asian studies. However, the causes associated with the contractor were reported in equal proportion by both regions (see Table 5).

Based on Table 5, the data showed that delays associated with owners were $1.5(60.0 / 40.0)$ times more prevalent in African than in Asian countries. On the contrary, the delay causes associated with external agents were 3.8 (79.2/20.8) times more prevalent in Asian than in African countries. Moreover, the measure of RR showed that the delay causes 
were $2.9(60.0 / 20.8)$ times more likely to be associated with the project owner, in African than in Asian countries. On the contrary, the delay causes were 2.0 (79.2/40.2) times more likely to be related to external agents, in Asian than in African countries.

\begin{tabular}{lcccc}
\multicolumn{5}{c}{ Table 5. Frequency of delays related to stakeholder by region. Source: self-elaboration. } \\
\hline Delay causes related to & Africa & Asia & Total \\
\hline Owner (35.7\%) & \% within category & $60.0 \%$ & $40.0 \%$ & $100 \%$ \\
Contractor (22.9\%) & & 16 & 16 & 32 \\
External agent (17.1\%) & $\%$ within category & $50.0 \%$ & $50.0 \%$ & $100 \%$ \\
& $\%$ within category & $20.8 \%$ & $79.2 \%$ & $100 \%$ \\
Designer and Consultant (15.0\%) & 9 & 12 & 21 \\
& $\%$ within category & $42.9 \%$ & $57.1 \%$ & $100 \%$ \\
Supplier and Subcontractor (9.3\%) & 10 & 3 & 13 \\
& $\%$ within category & $76.9 \%$ & $23.1 \%$ & $100 \%$ \\
\hline
\end{tabular}

\section{Influence level of the project delay causes}

This study ranked the first twenty influencing causes by the influence index (II) (see Table 6). The first two critical causes identified were payment delays to the contractor and financial difficulties of the owner, grouped within the "financial issues" category.

\begin{tabular}{clcccc}
\multicolumn{7}{c}{ Table 6. Level of influence of the top 20 delays according to the II. Source: self-elaboration. } \\
\hline Code & \multicolumn{1}{c}{ Delay Cause } & Frequency (\%) & RII & II & Rank \\
\hline C01 & Payment delays to contractor & 7.1 & 0.539 & 3.83 & 1 \\
C03 & Financial difficulties of owner & 6.4 & 0.500 & 3.20 & 2 \\
C13 & Inadequate contractor's experience & 4.3 & 0.275 & 1.18 & 3 \\
C29 & Shortage of equipment & 4.3 & 0.271 & 1.06 & 4 \\
C14 & Poor site management and supervision & 5.0 & 0.246 & 1.02 & 5 \\
C41 & Political situation & 2.9 & 0.221 & 0.79 & 6 \\
C38 & Poor communication with stakeholders & 3.6 & 0.214 & 0.80 & 7 \\
C30 & Shortage of materials & 3.6 & 0.204 & 0.77 & 8 \\
C20 & Inadequate project planning & 4.3 & 0.200 & 0.81 & 9 \\
C02 & Financial difficulties of contractor & 3.6 & 0.196 & 0.72 & 10 \\
C43 & Weather & 2.9 & 0.193 & 0.57 & 11 \\
C10 & Late decision making by owner & 3.6 & 0.189 & 0.57 & 12 \\
C09 & Land acquisition & 2.1 & 0.171 & 0.41 & 13 \\
C40 & Economy issues & 2.1 & 0.157 & 0.36 & 14 \\
C19 & Failures in design & 2.9 & 0.157 & 0.37 & 15 \\
C34 & Relocation of underground utilities & 2.1 & 0.136 & 0.33 & 16 \\
C36 & Unrealistic contract duration & 2.1 & 0.129 & 0.29 & 17 \\
C33 & Poor site investigation & 2.1 & 0.121 & 0.25 & 18 \\
C05 & Change orders due to the owner & 1.4 & 0.121 & 0.17 & 19 \\
C32 & Ground conditions & 2.1 & 0.114 & 0.24 & 20 \\
\hline
\end{tabular}

Consequently, an aggregated II was computed for each project management topic, based on their related delay causes (see Table 7). The study found that the first influencing category was financing issues, and the least influencing category was workforce/labor issues.

A chi-square test found statically evidence of relationship between project management topic (i.e., delay cause category) and region, at a confidence level $\alpha=0.05\left[\chi^{2}(4, n=86)=12.3, p=0.02\right]$. Likewise, this research found statistical evidence of association between stakeholder and region $\left[x^{2}(4, n=86)=14.2, p=0.01\right]$. Consequently, this study performed further analysis of the association between the top five project management topics and region, controlled by the variable "stakeholder." The analysis showed that within the owner category, "financial issues" were 3.7 (78.9/21.1) times more prevalent in African than in Asian countries. In contrast, within the contractor category, "financial issues" were 1.5 (60.0/40.0) times more prevalent in Asian than in African countries (see Table 8). 
Table 7. Level of influence of delay category according to the II. Source: self-elaboration

\begin{tabular}{lcc}
\multicolumn{1}{c}{ Category } & Aggregate II & Rank \\
\hline Financing issues & 7.75 & 1 \\
Equipment and material issues & 1.83 & 2 \\
External influences & 1.72 & 3 \\
Project planning issues & 1.47 & 4 \\
Contract management and skills & 1.09 & 5 \\
Change management & 0.74 & 6 \\
Design issues & 0.37 & 7 \\
Site management & 0.33 & 8 \\
Project characteristics & 0.24 & 9 \\
Workforce/labor issues & 0.00 & 10 \\
\hline
\end{tabular}

Table 8. Contingency table of project management category vs. region, controlled by stakeholder. Source: self-elaboration.

\begin{tabular}{|c|c|c|c|c|}
\hline Stakeholder & Delay Category & Africa & Asia & Total \\
\hline \multirow{6}{*}{ Owner } & Financial issues & 15 & 4 & 19 \\
\hline & $\%$ within category & 78.9 & 21.1 & 100 \\
\hline & Contract management and skills & 5 & - & 5 \\
\hline & $\%$ within category & - & - & - \\
\hline & Project planning issues & 4 & 8 & 12 \\
\hline & $\%$ within category & 33.3 & 66.7 & 100 \\
\hline \multirow{4}{*}{ Contractor } & Financial issues & 2 & 3 & 5 \\
\hline & $\%$ within category & 40.0 & 60.0 & 100 \\
\hline & Contract management and skills & 2 & 5 & 7 \\
\hline & $\%$ within category & 28.6 & 71.4 & 100 \\
\hline \multirow{6}{*}{ External Agent } & Contract management and skills & - & 7 & 7 \\
\hline & $\%$ within category & - & - & - \\
\hline & External influences & 4 & 11 & 15 \\
\hline & $\%$ within category & 26.7 & 73.3 & 100 \\
\hline & Equipment and materials issues & 1 & 1 & 2 \\
\hline & $\%$ within category & 50.0 & 50.0 & 100 \\
\hline \multirow{2}{*}{ Designer and Consultant } & Project planning issues & 1 & 2 & 3 \\
\hline & $\%$ within category & 33.3 & 66.7 & 100 \\
\hline \multirow{2}{*}{ Supplier and Subcontractor } & Equipment and materials issues & 8 & 3 & 11 \\
\hline & $\%$ within category & 72.7 & 27.3 & 100 \\
\hline
\end{tabular}

Note: Table shows only the top five categories related to project management

\section{Cause delay influence vs. Country's development}

Finally, this research analyzed the relationship between delay causes and economic development of countries ranked by the World Economic Forum (i.e., GCl indicators). For comparative purposes, this study organized the GCls by quintiles from the best competitiveness position (US, rank $=1^{\text {st }} ; \mathrm{GCl}=85.6$ ) to the lowest competitiveness position (Chad, rank = $140^{\text {th }} ; \mathrm{GCl}=35$ ). The fifth quintile [rank = 1 to $28 ; \mathrm{GCl}=86$ to 72 ]; the fourth quintile [rank $=29$ to $56 ; \mathrm{GCl}=71$ to 62 ]; the third quintile [rank = 57 to $84 ; \mathrm{GCl}=61$ to 57]; the second quintile [rank = 85 to $112 ; \mathrm{GCl}=56$ to 49]; and the first quintile [rank = 113 to $140 ; \mathrm{GCl}=48$ to 35 ] (Schwab, 2018).

Based on the $\mathrm{GCl}$ index, this research found that those African countries with delay causes related to "financing issues" and to "equipment and materials issues" belong to the first and second quintiles. Their rank positions varied between 85 and 140, and their corresponding GCls ranged between 56 and 35. Most of these delay causes were associated with the owner and the supplier/subcontractor categories. The average GDP per capita (US\$ 2018) of these countries was $\leq$ $\$ 2,000$.

On the other hand, those Asian countries with delay causes related to "external influences," "project planning issues" and "contract management" belong to the second and third quintiles, whose rank positions varied between 57 and 112 , and their corresponding GCls ranged between 61 and 49. Most of these delay causes were associated with the contractor, the external agent, and the designer/consultant categories. The average GDP per capita (US\$2018) of these countries was $\leq \$ 2,000$, as well. 
These findings show that developing countries with GDP (US\$2018) $\leq \$ 2,000$ may experience different delay causes in their road infrastructure projects, depending on the economic and geographical contexts. Road infrastructure projects are most likely to experience delays due to financial issues associated with the project owner, in countries with a GDP (US\$ 2018) $\leq \$ 2,000$ and a GCl score $\leq 56$. Moreover, these projects may experience delays due to equipment/material issues associated with the supplier/subcontractor. These delay causes would be more prevalent in projects undertaken in Africa than in Asia. Road infrastructure projects are most likely to experience delays due to either financial issues associated with the project contractor, planning issues related to the designer/consultant, or external influences related to the project outside agents, in countries with a GDP (US\$2018) $\leq \$ 2,000$ and a GCl score between 62 and 49 . These delay causes would be more prevalent in projects undertaken in Asia than in Africa.

\section{Recommendations for mitigating project delays}

This study proposes recommendations for mitigating the most critical delays herein ranked. The recommendations are organized into three groups according to the country's development indicators, the level of influence of the delay causes, and their respective category.

The first group of recommendations deals with financing issues and equipment/material issues and may apply for road infrastructure projects in developing countries with a GDP per capita (US\$2018) $\leq \$ 2,000$ and a GCI (2018) score $\leq 56$.

\section{Financing issues}

This category grouped causes related to either contractor or owner financing issues, especially related to payment delays to the contractor. Financial condition is one of the most important performance factors in construction companies (Khair et al., 2017; Orozco, Serpell, Molenaar, \& Forcael, 2014). Mitigation actions of owner-related delays, and due to financial issues, include: a) assure early and enough funding for the construction phase; b) provide economic resources to deal with unforeseen events along the construction time; c) undertake early feasibility studies; d) collaboratively develop a detailed cash flow plan with the project stakeholders; and e) adopt public-private partnership (PPP) models for public projects (Aforla, Woode, \& Amoah, 2016; Oyegoke \& Al Kiyumi, 2017; Rachid et al., 2018).

Daily activities of road construction projects involve high expenses for contractors such as payments for labor, equipment, and materials, among other items. Lacking cash could lead contractors to a critical situation that adversely affects the work progress, with a high chance of work disruption and delivery delays (Aforla et al., 2016; Honrao \& Desai, 2015). For dealing with late payment to contractors, some recommendations may include: a) simplification of payment approval procedures; b) adequate supervision to pay finished activities on time; c) development of a comprehensive financial plan and cash flow; and c) timely verification of invoices that allow the contractor to manage the payment requests (Mahamid et al., 2012; Marzouk \& El-Rasas, 2014; Nasir, Gabriel, \& Choudhry, 2015).

\section{Equipment and material issues}

Causes related to availability, failures, and maintenance of equipment, as well as to materials management issues, were grouped into this category. Because road projects belong to heavy construction activities, with a high degree of mechanization and high volumes of materials, the failures and shortage of these resources are potentially delay factors (Aforla et al., 2016; Santoso \& Soeng, 2016).

Recommendations to mitigate delays due to equipment issues, and associated with the project supplier/subcontractor, encompass: a) planning equipment maintenance programs at the construction site; b) assuring the availability of the necessary equipment for scheduled activities; c) adopting contingency measures to replace machinery with low productivity; and d) investing in new and reliable machinery (Mahamid et al., 2012; Santoso \& Soeng, 2016).

On the other hand, recommendations related to materials issues include: a) undertaking an effective supply chain management strategy; b) early integration of the supply chain into the project's life cycle; c) timely definition of suppliers and quarries of required materials; and d) proper planning procurement, transportation, storage, and access to construction materials (Eriksson, 2015; Khair et al., 2017; Oyegoke \& Al Kiyumi, 2017).

The second group of recommendations deals with delay categories related to external influences, project planning issues, and contract management and skill. These recommendations may apply for road infrastructure projects in developing countries with a GDP per capita (US\$2018) $\leq \$ 2,000$ and a GCl (2018) score between 62 and 49 . 


\section{External influences}

This category grouped factors with control outside of the project dominion, which could compromise the schedule performance, such as weather conditions (Santoso \& Soeng, 2016) or political/economic risks at several stages of the project's life cycle (Steffen \& Papakonstantinou, 2015).

Mitigation actions of delays related to economic-political influences, and associated with external agents, include: a) shortening the time between planning and construction to avoid inflation problems; b) acquiring insurance policies for economic and political risks; c) keeping up strong relationships and communication with government agencies; and d) monitoring political and social environment (Steffen \& Papakonstantinou, 2015; Wang, Tiong, Ting, \& Ashley, 2000).

\section{Project planning issues}

Causes related to road planning, site investigation, and land acquisition were grouped into this category. Effective planning is another important factor for road projects' success, taking into account the high investment done in the early stages of the project, their constraints, and uncertainties, and the different interests of the project's stakeholders (Emam, Farrell, \& Abdelaal, 2015; Santoso \& Soeng, 2016).

Recommendations related to project planning issues and associated with the project's designer/consultant are: a) implementing of the Last Planner System (LPS) or any other project planning tool (Daniel, 2017); b) assessing the availability of resources and restrictions for construction activities (Rachid et al., 2018); c) allocating sufficient time and effort for planning, design, and documentation (Mahamid et al., 2012); and d) implementating of digital simulations such as BIM nD to support planning activities (Costin, Adibfar, Hu, \& Chen, 2018; Sánchez, Galvis, Porras, Ardila, \& Martínez, 2017).

\section{Contract management and skills}

The causes grouped into this category included contractor-owner experience, communication between stakeholders, claims/disputes resolution, and contract administration, among others. Particularly, road projects require dealing successfully with project stakeholders to achieve all goals effectively along the project's lifecycle (Honrao \& Desai, 2015).

Recommendations to mitigate contractor-related delays due to contract management and skills are: a) assuring a proper level of experience of the contractor, according to the characteristics of the project (Rachid et al., 2018); b) ensuring a qualified experience of the personnel at the construction site to be hired (Famiyeh, Amoatey, Adaku, \& Agbenohevi, 2017); and c) adopting effective selection methods of contractors, different from the lowest bidder approach (Santoso \& Soeng, 2016).

Finally, the third group of recommendations deals with delay categories related to change management, design issues, site management, project characteristics, and workforce/labor issues. These recommendations may apply for road infrastructure projects in developing countries with GDP per capita (US\$2018) $\leq \$ 2,000$ and GCI (2018) score $\leq 62.0$.

\section{Change management}

This category grouped causes related to scope change and decision-making. Under complex environments with many and non-aligned interests of the project's stakeholders, project management teams must deal with both various and frequent changes and late decision-making. If the interventions are frequent, and without any reason, it may generate restrictions on the activities and their consequent delays (Honrao \& Desai, 2015).

Mitigation actions of owner-related delays due to change management include: a) implementing effective change control systems; b) including clear contractual conditions that regulate the influence of stakeholders; c) aligning the project's objectives and requirements with the project stakeholders; and d) assessing any change's effect on project performance (Amoatey, Ameyaw, Adaku, \& Famiyeh, 2015; Yates \& Eskander, 2002).

\section{Design issues}

This category grouped causes such as late approvals, design changes, errors/omissions of drawings, and poor specifications. During construction time, several changes occur due to design failures, errors, and incomplete information (Aforla et al., 2016). These issues could affect the work continuity at the construction site and generate delays. 
Recommendations to mitigate delays due to design issues, which are generally associated with the project's designer/consultant, are: a) achieving a high maturity level of the design before beginning the construction work; $b$ ) involving stakeholders into the design processes; and c) implementating Building Information Modeling (BIM) technologies (Bongiorno, Bosurgi, Carbone, Pellegrino, \& Sollazzo, 2019; Costin et al., 2018; Othuman Mydin, Sani, Taib, \& Mohd Alias, 2014).

\section{Site management}

This category grouped causes related to management and supervision of work at the construction site. Ineffective site management leads to quality issues, accidents, rework, and unwanted situations that could turn into delays (Aforla et al., 2016).

Recommendations to avoid contractor-related delays due to site management include: a) implementing new site management technologies; b) implementing lean construction techniques; c) planning the site work to avoid overallocation of resources; d) hiring qualified personnel; and f) implementing last planner system and earned value management for controlling (Al Tabtabai, 2002; Famiyeh et al., 2017; Mate \& Hinge, 2015; Tezel, Koskela, \& Aziz, 2017).

\section{Project characteristics}

This category grouped project size and ground conditions as delay causes. When undefined service networks are discovered during the construction time, the relocation becomes an unforeseen activity that may produce delays (Honrao \& Desai, 2015).

Mitigation actions associated with the designer/consultant, and related project characteristics include: a) investigating underground conditions of the construction site; b) using radar systems and laser technologies for localization of underground utilities; $c$ ) involving construction site manager at the planning stage; and d) adopting BIM tools to check clashes of underground utility lines (Chan \& Lin, 2014; Kamanga \& Steyn, 2013; Sărăcin, 2017).

\section{Workforce/labor issues}

Finally, this category grouped causes related to the project personnel and construction crews such as productivity, training, and availability, among others. The low productivity of construction crews can adversely affect the duration of the project activities. Productivity can be affected by several factors such as training, skills, experience, motivation, delays in payments, wages, among others (Mahamid, 2017b).

Recommendations to mitigate contractor-related delays due to labor issues include: a) monitoring labor productivity at the construction site; b) implementing incentives strategies for early completion of activities; c) implementing effective selection of workers; d) developing training programs focused on improving knowledge and skills for workers and personnel; e) implementing effective communication strategies with (Othuman Mydin et al., 2014; Patil, Gupta, Desa, \& Sajane, 2013).

\section{Conclusions}

Delays of road projects can significantly affect the country's development, taking into account the high investment involved in the construction and the adverse effect on the economic growth and competitiveness (Amare, Quezon, \& Busier, 2017). Therefore, this research evaluated the most critical delay causes of road projects in developing countries to propose mitigation actions according to the development indicators of countries. As a contribution to the risk analysis, countries with similar development indicators can adopt these recommendations for their road infrastructure projects.

Based on a final sample of 14 primary studies from African countries (50\%) and Asian countries (50\%), this research found interesting insights for delay analysis. The study found that the categories of delay causes proposed by primary studies are not mutually exclusive. There is no consensus among academics and practitioners on standardizing causes and categories. Therefore, this study suggested a mutually exclusive categorization of delay causes based on project management topics and project stakeholders. This categorization allowed proposing a framework of activities for further risk analysis of schedule performance in developing countries. 
According to these proposed categories, the study found that those causes related to financing issues were the most reported by the primary studies, followed by causes related to contract management. Moreover, the study found that one-third of the leading causes was associated with project owners and another third with contractors/subcontractors.

This study found that developing countries with a GDP (US\$2018) $\leq \$ 2,000$ may experience different delay causes in their road infrastructure projects, depending on the economic and geographical contexts. Road infrastructure projects are most likely to experience delays due to financial issues associated with the project owner, in countries with a GDP (US\$2018) $\leq \$ 2,000$ and a GCl score $\leq 56$. These projects may experience delays due to equipment/material issues associated with the supplier/subcontractor. These delay causes would be more prevalent in projects undertaken in Africa than in Asia. In countries with a GDP (US\$2018) $\leq \$ 2,000$ and a GCl score between 62 and 49, road infrastructure projects are most likely to experience delays due to either financial issues associated with the project contractor, planning issues related to the designer/consultant, or external influences related to the project outside agents,. These delay causes are more prevalent in projects undertaken in Asia than in Africa.

This study found that most critical delay causes of road projects are associated with financing issues of the project's owner. Because the public character of the majority of owners of road infrastructure projects and the big amount of public resources used for funding these projects, this study advocates for recommendations to avoid delays in road projects, especially in developing countries.

Thus, the study proposes three groups of recommendations for dealing with the most influencing delay causes. The first group may apply for road infrastructure projects in developing countries with a GDP per capita ( $\$$ US2018) $\leq \$ 2,000$ and $\mathrm{GCl}(2018)$ score $\leq 56$. These recommendations deal with financing issues and equipment/material issues. The second group may apply for road infrastructure projects in developing countries with GDP (\$US2018) $\leq \$ 2,000$ and GCI (2018) score between 62 and 49 . These recommendations are for mitigating causes related to external influence, planning issues, and contract management and skill influence. Finally, the third group may apply for road infrastructure projects in developing countries with GDP (\$US2018) $\leq \$ 2,000$ and GCl score $(2018) \leq 62$. These recommendations are for mitigating causes related to change management, design issues, site management, project characteristics, and workforce/labor issues.

\section{Acknowledgments}

Omar Sánchez wants to acknowledge and thank Colciencias for the sponsorship and support through the "Convocatoria Doctorados Nacionales-2015" program. Colciencias is The Administrative Department of Science, Technology, and Innovation, a Colombian government agency that supports fundamental and applied research in Colombia.

References

Aforla, B., Woode, A., \& Amoah, D. K. (2016). Causes of delays in highway construction projects in Ghana. Civil and Environmental Research, 8(11), 69-76.

Agyekum, G., \& Knight, A. (2017). The professionals' perspective on the causes of project delay in the construction industry. Engineering Construction Architectural Management, 24(5), 828-841. https://doi.org/10.1108/ECAM-03-2016-0085

Al Tabtabai, H. (2002). Causes for delays in construction projects in Kuwait. Engineering Journal of the University of Qatar, 15(February), 19-37.

Alfakhri, A., Ismail, A., Muhamad, A. K., Arhad, I., \& Irtema, H. (2017). A conceptual model of delay factors affecting road construction projects in Libya. Journal of Engineering Science and Technology, 12(12), 3286-3298.

Amare, Y., Quezon, E. T., \& Busier, M. (2017). Causes of delays during construction phase of road projects due to the failures of contractor, consultant, and employer in Addis Ababa City Road Authority. International Journal of Scientific \& Engineering Research, 8(3), 15-25.

Amoatey, C., Ameyaw, Y. A., Adaku, E., \& Famiyeh, S. (2015). Analysing delay causes and effects in Ghanaian state housing construction projects. International Journal of Managing Projects in Business, 8(1), 198-214. https://doi.org/10.1108/IJMPB-04-2014-0035

Amoatey, C., \& Okanta, A. (2017). Exploring critical road project delay factors in Ghana. Journal of Facilities Management, 15(2), 110-127. Retrieved from https://doi.org/10.1108/JFM-09-2016-0036

Arditi, D., Nayak, S., \& Damci, A. (2017). Effect of organizational culture on delay in construction. International Journal of Project Management, 35(2), 136-147. https://doi.org/10.1016/j.jproman.2016.10.018

Aziz, R., \& Abdel-hakam, A. (2016). Exploring delay causes of road construction projects in Egypt. Alexandria Engineering Journal, 55(2), 1515-1539. https://doi.org/10.1016/j.aej.2016.03.006

Bongiorno, N., Bosurgi, G., Carbone, F., Pellegrino, O., \& Sollazzo, G. (2019). Potentialities of a highway alignment optimization method in an I-BIM environment. Periodica Polytechnica Civil Engineering, 1-10. https://doi.org/10.3311/PPci.12220 
Borrego, M., Foster, M., \& Froyd, J. (2014). Systematic literature reviews in engineering education and other developing interdisciplinary fields. Journal of Engineering Education, 103(1), 45-76. https://doi.org/10.1002/jee.20038

Budayan, C. (2019). Evaluation of delay causes for BOT projects based on perceptions of different stakeholders in Turkey. Journal of Management in Engineering, 35(1), 1-13. https://doi.org/10.1061/(ASCE)ME.1943-5479.0000668

Chan, J. R., \& Lin, H. S. (2014). Preliminary study on application of building information modeling to underground pipeline management. In Application of Nanotechnology in Pavements, Geological Disasters, and Foundation Settlement Control Technology (Vol. 1, pp. 69-76). Yichang, Hubei, China.

Cooper, H., Hedges, L., \& Valentine, J. (2009). The Handbook of Research Synthesis and Meta-Analysis. New York, United States: Russell Sage Foundation.

Costin, A., Adibfar, A., Hu, H., \& Chen, S. S. (2018). Building Information Modeling (BIM) for transportation infrastructure - Literature review , applications, challenges, and recommendations. Automation in Construction, 94(June), 257-281. https://doi.org/10.1016/j.autcon.2018.07.001

Daniel, E. I. (2017). Exploratory study into the use of Last Planner ${ }^{\circledR}$ System and collaborative planning for construction process improvement. Nottingham Trent University.

Durdyev, S., Omarov, M., \& Ismail, S. (2017). Causes of delay in residential construction projects in Cambodia. Cogent Engineering, 4(1), 1-12. https://doi.org/10.1080/23311916.2017.1291117

Elawi, G. S., Algahtany, M., Kashiwagi, D., \& Sullivan, K. (2015). Major factors causing construction delays in Mecca. Journal for the Advancement of Performance Information and Value, $7(1), 1-11$.

Elliott, A., \& Woodward, W. (2007). Statistical analysis quick reference guidebook: with SPSS example. Los Angeles, United States: SAGE.

Ellis, R. D. (2003). The root causes of delays in highway construction. In Presentation at the 82nd Annual Meeting of the Transportation Research Board (pp. 1-16). Washington, USA.

Emam, H., Farrell, P., \& Abdelaal, M. (2015). Causes of delay on infrastructure projects in Qatar. In Proceedings of 31st Annual ARCOM Conference (pp. 773-782). Linconln, UK: Association of Researchers in Construction Management.

Eriksson, P. E. (2015). Partnering in engineering projects: four dimensions of supply chain integration. Journal of Purchasing and Supply Management, 21(1), 38-50. https://doi.org/10.1016/j.pursup.2014.08.003

Famiyeh, S., Amoatey, C. T., Adaku, E., \& Agbenohevi, C. S. (2017). Major causes of construction time and cost overruns: A case of selected educational sector projects in Ghana. Journal of Engineering, Design and Technology, 15(2), 181-198. https://doi.org/10.1108/JEDT-11-2015-0075

Hadithi, B. (2018). An investigation into factors causing delays in highway construction projects in Iraq. In MATEC Web of Conferences (Vol. 162, pp. 1-11). https://doi.org/https://doi.org/10.1051/matecconf/201816202035

Honrao, Y., \& Desai, D. (2015). Study of delay in execution of infrastructure projects - highway construction. International Journal of Scientific and Research Publications, 5(6), 1-8.

Kadry, M., Osman, H., \& Georgy, M. (2017). Causes of construction delays in countries with high geopolitical risks. Journal Construction Engineering and Management, 143(2), 1-11. https://doi.org/10.1061/(ASCE)CO.1943-7862.0001222.

Kaliba, C., Muya, M., \& Mumba, K. (2009). Cost escalation and schedule delays in road construction projects in Zambia. International Journal of Project Management, 27(5), 522-531. https://doi.org/10.1016/j.ijproman.2008.07.003

Kamanga, M., \& Steyn, W. (2013). Causes of delay in road construction projects in Malawi. Journal of the South African Institution of Civil Engineering, $55(3), 79-85$

Kavuma, A., Ock, J., \& Jang, H. (2019). Factors influencing time and cost overruns on freeform construction projects. KSCE Journal of Civil Engineering, 23(4), 1442-1450. https://doi.org/10.1007/s12205-019-0447-x

Khair, K., Mohamed, Z., Mohammad, R., Farouk, H., \& Ahmed, M. (2017). A management framework to reduce delays in road construction projects in Sudan. Arabian Journal for Science and Engineering, 43(4), 1925-1940. https://doi.org/10.1007/s13369-017-2806-6

Mahamid, I. (2017a). Analysis of schedule deviations in road construction projects and the effects of project physical characteristics. Journal of Financial Management of Property and Construction, 22(2), 192-210. https://doi.org/10.1108/JFMPC-07-2016-0031

Mahamid, I. (2017b). Schedule delay in Saudi Arabia road construction projects: size, estimate, determinants and effects. International Journal of Architecture, Engineering and Construction, 6(3), 51-58. https://doi.org/10.7492/IJAEC.2017.017

Mahamid, I., Bruland, A., \& Dmaidi, N. (2012). Causes of Delay in Road Construction Projects. Journal of Management in Engineering, 28(July), 300310. https://doi.org/10.1061/(ASCE)ME.1943-5479.0000096.

Mahdi, I., \& Soliman, E. (2018). Significant and top ranked delay factors in Arabic Gulf countries. International Journal of Construction Management, 1-14. https://doi.org/10.1080/15623599.2018.1512029

Marzouk, M. M., \& El-Rasas, T. I. (2014). Analyzing delay causes in Egyptian construction projects. Journal of Advanced Research, 5(1), 49-55. https://doi.org/10.1016/j.jare.2012.11.005

Mate, R., \& Hinge, G. (2015). Delay mitigation in the construction industry. International Journal of Engineering Research \& Technology, 4(6), 172176.

Nasir, A. R., Gabriel, H., \& Choudhry, R. (2015). Cost and time overruns in highway projects of Pakistan. In Sixth International Conference on Construction in the 21st Century (pp. 69-76). Kuala Lumpur, Malaysia. 
Orozco, F., Serpell, A., Molenaar, K., \& Forcael, E. (2014). Modeling competitiveness factors and indexes for construction companies: findings of Chile. Journal of Construction Engineering and Management, 140(April). https://doi.org/http://dx.doi.org/10.1061/(ASCE)CO.1943-7862.0000462

Othuman Mydin, M. A., Sani, N. M., Taib, M., \& Mohd Alias, N. (2014). Imperative causes of delays in construction projects from developers' outlook. In MATEC Web of Conferences (Vol. 10, pp. 1-6). https://doi.org/10.1051/matecconf/20141006005

Oyegoke, A. S., \& Al Kiyumi, N. (2017). The causes, impacts and mitigations of delay in megaprojects in the Sultanate of Oman. Journal of Financial Management of Property and Construction, 22(3), 286-302. https://doi.org/10.1108/JFMPC-11-2016-0052

Pai, S., Patnaik, B., Mittal, A., \& Anand, N. (2018). Identification of risks causing time and cost overrun in roads and highway projects in India. International Journal of Civil Engineering and Technology, 9(3), 683-697.

Patil, S., Gupta, A., Desa, D., \& Sajane, A. (2013). Causes of delay in Indian transportation infrastructure projects. International Journal of Research in Engineering and Technology, 2(11), 71-80.

Rachid, Z., Toufik, B., \& Mohammed, B. (2018). Causes of schedule delays in construction projects in Algeria. International Journal of Construction Management, 1-11. https://doi.org/10.1080/15623599.2018.1435234

Sánchez, O., Castañeda, K., Herrera, R. F., \& Pellicer, E. (2019). Benefits of Last Planner ${ }^{\circledR}$ System in mitigation of delay causes in road infrastructure projects. In XI Simpósio Brasileiro de Gestão e Economia da Construção (pp. 1-8). Londrina, Paraná, Brasil. Retrieved from https://www.antaceventos.net.br/index.php/sibragec/sibragec2019/paper/viewFile/246/334

Sánchez, O., Galvis, J., Porras, H., Ardila, Y., \& Martínez, C. (2017). BrIM 5D models and Lean Construction for planning work activities in reinforced concrete bridges. Revista Facultad de Ingeniería, 26(46), 39-50. https://doi.org/http://doi.org/10.19053/01211129.v26.n46.2017.7314

Santoso, D. S., \& Soeng, S. (2016). Analyzing delays of road construction projects in Cambodia: causes and effects. Journal of Management in Engineering, 32(6), 1-11. https://doi.org/10.1061/(ASCE)ME.1943-5479.0000467.

Sărăcin, A. (2017). Using georadar systems for mapping underground utility networks. Procedia Engineering, 209, 216-223. https://doi.org/10.1016/j.proeng.2017.11.150

Schwab, K. (2018). The Global Competitiveness Report 2018.

Sohu, S., Chandio, A. F., \& Keleemullah. (2019). Identification of causes and minimization of delays in highway projects of Pakistan. Mehran University Research Journal of Engineering \& Technology, 38(1), 103-112. https://doi.org/10.22581/muet1982.1901.09

Steffen, B., \& Papakonstantinou, V. (2015). Mitigation of political \& regulatory risk in infrastructure projects introduction and landscape of risk.

Tezel, A., Koskela, L., \& Aziz, Z. (2017). The management of operations lean thinking in the highways construction sector: motivation, implementation and barriers. Production Planning \& Control, 7287(December), 1-23. https://doi.org/10.1080/09537287.2017.1412522

Venkateswaran, C. B., \& Murugasan, R. (2017). Time delay and cost overrun of road over bridge (ROB) construction projects in India. Journal of Construction in Developing Countries, 22(November), 79-96. https://doi.org/10.21315/jcdc2017.22.supp1.5

Wang, S., Tiong, R., Ting, S., \& Ashley, D. (2000). Evaluation and management of political risks in China's BOT projects. Journal of Construction Engineering and Management, 126(3), 242-250. https://doi.org/10.1061/(ASCE)0733-9364(2000)126:3(242)

Yates, J., \& Eskander, A. (2002). Construction total project management planning issues. Project Management Journal, (March), 37-48. https://doi.org/https://doi.org/10.1177/875697280203300107 